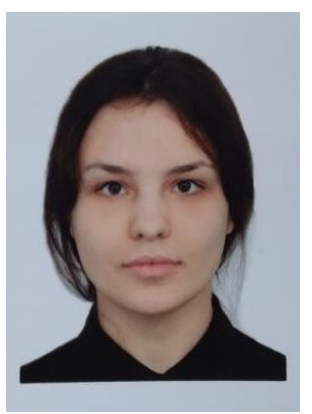

\title{
БАТОНЧИКИ-СНЕКИ ДЛЯ СПОРТИВНОГО ПИТАНИЯ: МАРКЕТИНГОВОЕ ИССЛЕДОВАНИЕ И ТЕХНОЛОГИЯ
}

\author{
Ю. О. Некрасова, студентка 4 курса, \\ e-mail: yulya.nekrasova.1998@mail.ru \\ ФГБОУ ВО «Калининградский государственный \\ технический университет» \\ О. Я. Мезенова, д.т.н., профессор, \\ e-mail: mezenova@klgtu.ru \\ ФГБОУ ВО «Калининградский государственный \\ технический университет»
}

Представлен анализ результатов маркетингового исследования предпочтений потребителей в области спортивного питания Калининграда и Калининградской области. Изучены предпочтения потребителей при выборе спортивных пищевых продуктов. Часто покупаемая форма спортивного питания - батончик, что соответствует форме проектируемого продукта протеиновый батончик - снек. Обоснована актуальность использования протеиновых гидролизатов, полученных из голов копченой кильки, и вторичного яблочного сырья в составе протеинового продукта. Разработана технологическая схема производства батончика-снека, предназначенного для спортивного питания.

Ключевые слова: маркетинговое исследование, спортивное питание, батончик-снек, протеиновые гидролизаты, яблочный жмых

\section{ВВЕДЕНИЕ}

Профессиональные спортсмены и люди, которые активно занимаются спортом и придерживаются активного образа жизни, представляют собой весьма значительную часть нашего общества. Поэтому важнейшим условием достижения спортивного успеха и сохранения здоровья является сбалансированное по химическому составу питание [5]. Современные продукты спортивного питания представляют собой биологически активные композиции, которые характеризуются высокой пищевой и энергетической ценностью и направленной эффективностью [1, 9].

За последние несколько лет ассортимент продуктов спортивного питания претерпел значительные изменения. Если раньше данный сегмент был представлен в основном в виде биологически активных добавок (БАД), то сейчас преобладают полноценные продукты питания батончики, печенье, изотонические напитки, коктейли, соусы, джемы. Причем каждый продукт характеризуется повышенным содержанием веществ «спортивной» направленности - белка, витаминов, пищевых волокон, минеральных веществ и т. д.

У спортсменов, а также у людей, которые ведут активный образ жизни, отмечаются повышенные физиологические потребности в белке как главном пищевом нутриенте. Это условие является основным критерием при разработке нового продукта спортивного питания. Белки нужны, чтобы поддерживать адекватный синтез белка собственного организма и выработку энергии, а также достаточную иммунную функцию и хорошую целостность кишечника в условиях множественных стрессов, частых и интенсивных упражнений. 
Потребность в белке увеличивается вместе повышением интенсивности и продолжительности физических нагрузок; следовательно, он должен быть включен в прием пищи до и после фактической работы и регулярно в течение дня [3].

В пищевых продуктах спортивного назначения в качестве источника белка используются протеиновые гидролизаты. Сравнительно недавно было открыто перспективное направление по использованию данных гидролизатов, полученных из животного и растительного сырья, в составе продуктов специализированного питания [4]. Для их производства наиболее часто применяют казеиновый белок, белки молочной сыворотки и соевые. Каждый белковый гидролизат представляет собой сложную смесь пептидов разной длины цепи вместе со свободными аминокислотами. В таком виде гидролизаты усваиваются более эффективно, так как не требуют переваривания и быстро адсорбируются в организме [7].

Другим сырьем для получения протеиновых гидролизатов может служить вторичное рыбное. В Калининградской области 11 рыбоперерабатывающих заводов производят консервы «Шпроты в масле» из балтийской кильки и салаки. При этом в виде отходов в сутки накапливаются от 2 до 8 т удаляемых голов копченой рыбы. Однако копченое вторичное сырье (головы копченой кильки) богато органическими веществами, прежде всего, натуральными белками, жирами и минеральными компонентами. В КГТУ на кафедре пищевой биотехнологии ведутся исследования по получению добавок протеинового, липидного, минерализованного и смешанного органического состава путем высокотемпературного гидротермолиза с применением протеолитических ферментов для полного извлечения ценных веществ [6]. Полученный в результате данной технологии протеиновый гидролизат отличается высоким содержанием белка (до 80\%) и может найти применение в специализированном спортивном питании.

Не менее важными в спортивном питании являются добавки из растительных компонентов. Перспективной добавкой можно считать вторичное сырье производства соков прямого отжима - яблочных выжимок. Яблочные выжимки являются источником углеводов, в особенности пищевых волокон, которые способствуют быстрому всасыванию пищи и получению энергии. Как известно, при интенсивных физических нагрузках в организме образуются свободные радикалы, вследствие чего растет напряжение в мышцах и человек устает. Яблочный жмых содержит витамины и флавоноиды, которые проявляют антиоксидантную активность. Важное значение имеют и минеральные вещества вторичного яблочного сырья, такие как кальций, магний, фосфор, необходимые для людей в состоянии перенапряжения и стресса [8].

\section{ОБЪЕКТ ИССЛЕДОВАНИЯ}

Объектом исследования является протеиновый батончик-снек, совершенствование его рецептуры путем применения в качестве источника белка протеиновых гидролизатов, полученных из голов копченой кильки, и вторичного яблочного сырья как источника биологически активных веществ. Такой батончик-снек относится к высокобелковым продуктам. Согласно ГОСТ 34006-2016 высокобелковые продукты для питания спортсменов - это продукты, состоящие из белковых компонентов животного и/или растительного происхождения, с содержанием белка не менее $20 \%$ от энергетической ценности продукта, предназначенные для питания спортсменов с целью контроля мышечной и жировой массы тела, а также повышения скоростно-силовых показателей [2].

\section{ЦЕЛИ И ЗАДАЧИ ИССЛЕДОВАНИЯ}

Цель настоящего исследования заключается в выявлении востребованности и разработке технологии нового протеинового продукта - батончика-снека, предназначенного для спортивного питания. Для выявления предпочтений при выборе спортивного питания, а также решения вопроса о востребованности нового продукта - протеинового батончика первоначально обосновывали его состав. Предложено изготавливать снеки с применением 
протеинового гидролизата, полученного из голов копченой кильки, в качестве источника полноценного и сбалансированного по аминокслотному составу белка, а также вторичного яблочного сырья в качестве источника биологически активных веществ растительного происхождения (витаминов, пищевых волокон, минеральных компонентов). Конкретными задачами исследования являлись маркетинговое исследование среди потенциальных респондентов и обоснование структурной технологической схемы изготовления батончиков-снеков.

\section{МЕТОДЫ ИССЛЕДОВАНИЯ}

При проведении маркетингового исследования были разработаны анкеты, учитывающие возраст и пол респондентов, отношение к спортивному образу жизни и спортивному питанию, предпочтения при выборе специализированной продукции. С применением данных анкет было проведено маркетинговое исследование потенциальных потребителей новой продукции. В результате полученных данных, с учетом наработанных ранее экспериментальных результатов, была разработана технология производства нового протеинового продукта.

\section{РЕЗУЛЬТАТЫ ИССЛЕДОВАНИЯ}

Основным направлением при проведении маркетингового исследования являлось изучение спроса на продукцию - спортивное питание, оценку приемлемости ее качества, анализ необходимости расширения отечественного ассортимента. Обозначенные индикаторы достигались путем социологического опроса респондентов в количестве 106 человек. Результаты маркетингового опроса представлены на диаграммах $1-8$.

В опросе участвовало 59\% женщин и $41 \%$ мужчин (рис. 1), среди них: 9,0 \% - в возрасте до 18 лет, 62,0 \% - 18 - 25 лет, 19,0 \% - 26 - 35 лет и 10,0 \% - 36 - 55 лет (рис. 2). Отвечая на вопрос, необходимо ли употреблять спортивное питание, треть опрошенных (32,0\%) уверена, что нужно всем, кто ведет здоровый образ жизни и занимается спортом (рис. 3). На вопрос, знакомы ли со специализированными продуктами с высоким содержанием белка, большинство опрошенных ответили, что знакомы - 60 \%, не знакомы - $23 \%$, а 23 \% и 3 \% - слышали или интересовались данными продуктами (рис. 4).

Наибольшим спросом среди опрошенных пользуются протеиновые батончики $(55,7$ \%) и протеиновые коктейли (28,3 \%) (рис. 5). По результатам можно сделать вывод, что и те и другие занимают весомое положение среди всего ассортимента спортивного питания. Часто встречающиеся в составе продуктов спортивного питания белки относятся к белкам молочной сыворотки (сывороточные) $(56,6 \%$ ) и изолятам молочного белка $(58,5 \%)$, наименее популярны белки рыбного сырья - 17,0 \% (рис. 6). Поэтому считается целесообразным и актуальным производство батончиков-снеков на основе вторичного рыбного сырья как источника полноценного белка.

При выборе спортивного питания наибольший акцент респонденты делают на состав $(84,0 \%)$, далее идут натуральные компоненты $(60,4 \%)$, цена $(50,0 \%)$ и вкус и запах продукта $(50,0 \%)$ (рис. 7). Таким образом, для хорошей реализации продукции главный акцент должен быть сделан на состав желательно натуральных компонентов, вкус и запах и приемлемую цену.

Попробовать новый продукт - батончик-снек на основе протеинового гидролизата, полученного из голов копченой кильки, и вторичного яблочного сырья согласились 57,0 \% опрошенных (рис. 8). 


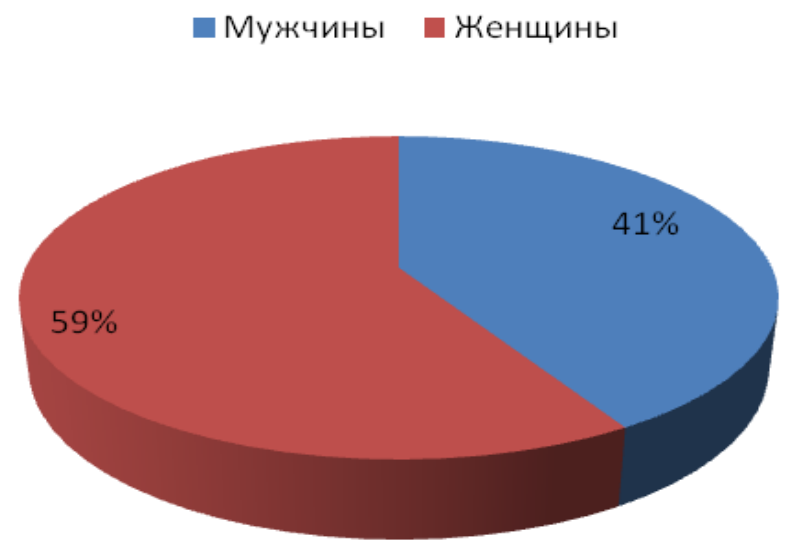
Рисунок 1 - Соотношение респондентов по половому признаку, \%

До 18 лет $\quad 18$ - 25 лет $\quad 26$ - 35 лет $\quad 36$ - 55 лет $\quad 56$ лет и старше

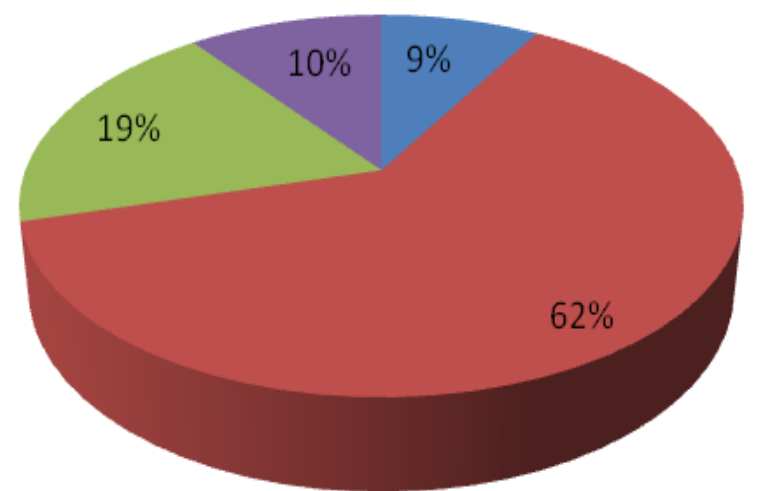

Рисунок 2 - Соотношение респондентов по возрасту, \%

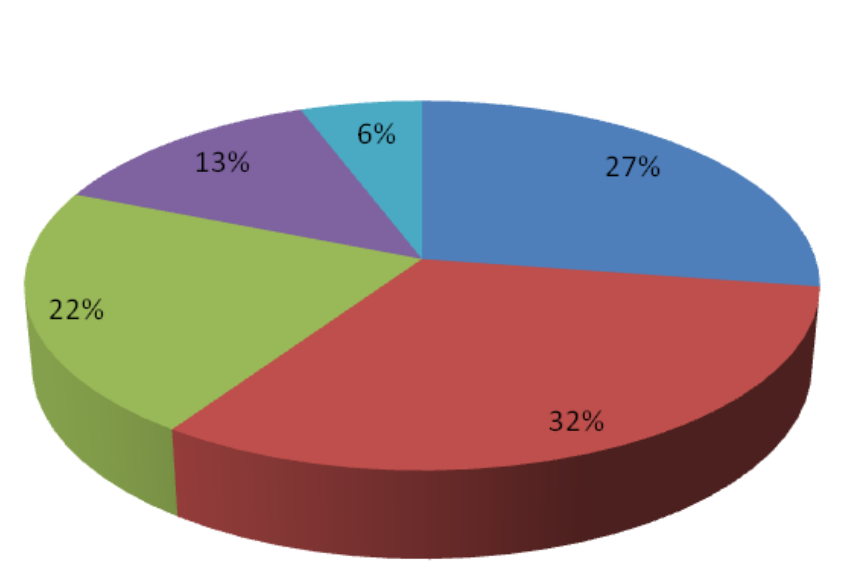
- Необходимо только профессиональным спортсменам
- Необходимо всем, кто ведет здоровый образ жизни и занимается спортом
- Необходимо только тем, кто тренируется постоянно и без длительных перерывов
позможно, кому-то оно и необходимо, но только не мне
— Затрудняюсь ответить

Рисунок 3 - Соотношение респондентов по употреблению спортивного питания, \% 


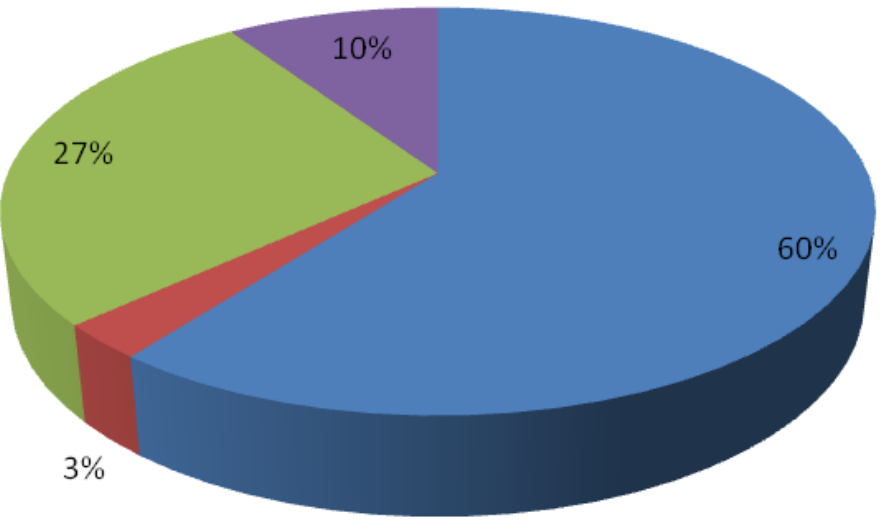

Рисунок 4 - Количество респондентов, знакомых/не знакомых со специализированными продуктами с высоким содержанием белка, \%

Протеиновые смеси для приготовления блюд

Протеиновые конфеты

Протеиновые коктейли

Протеиновое печенье

Протеиновые батончики

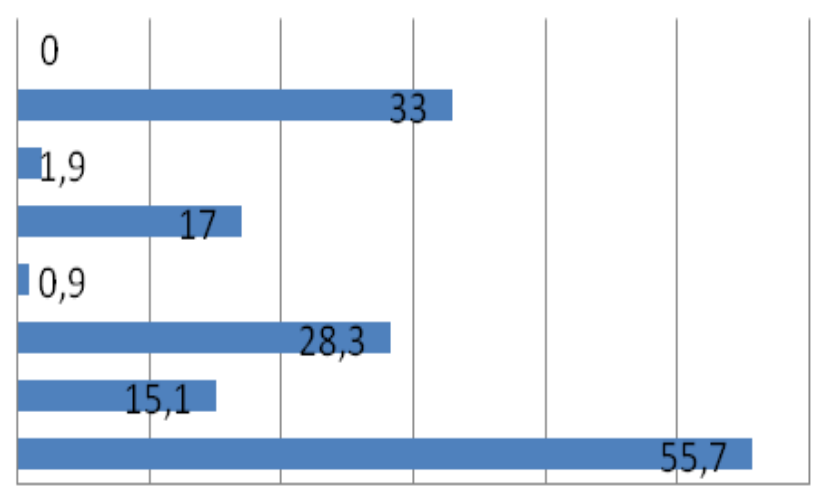

$\begin{array}{lllllll}0 & 10 & 20 & 30 & 40 & 50 & 60\end{array}$

Рисунок 5 - Предпочтения по выбору спортивного питания, \%

Другое (яичный белок, растительные белки и

т.д.)

Белки рыбного сырья ( коллагеновые)

Изолят молочного белка

Соевые белки

Сывороточные белки

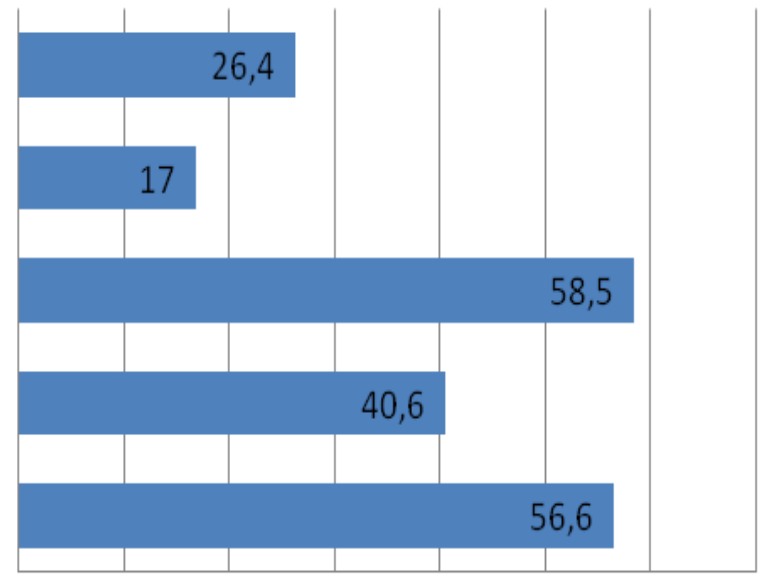

$\begin{array}{lllllll}0 & 10 & 20 & 30 & 40 & 50 & 60\end{array}$

Рисунок 6 - Часто встречающиеся протеины в составе продуктов спортивного питания по мнению опрощенных респондентов, \% 


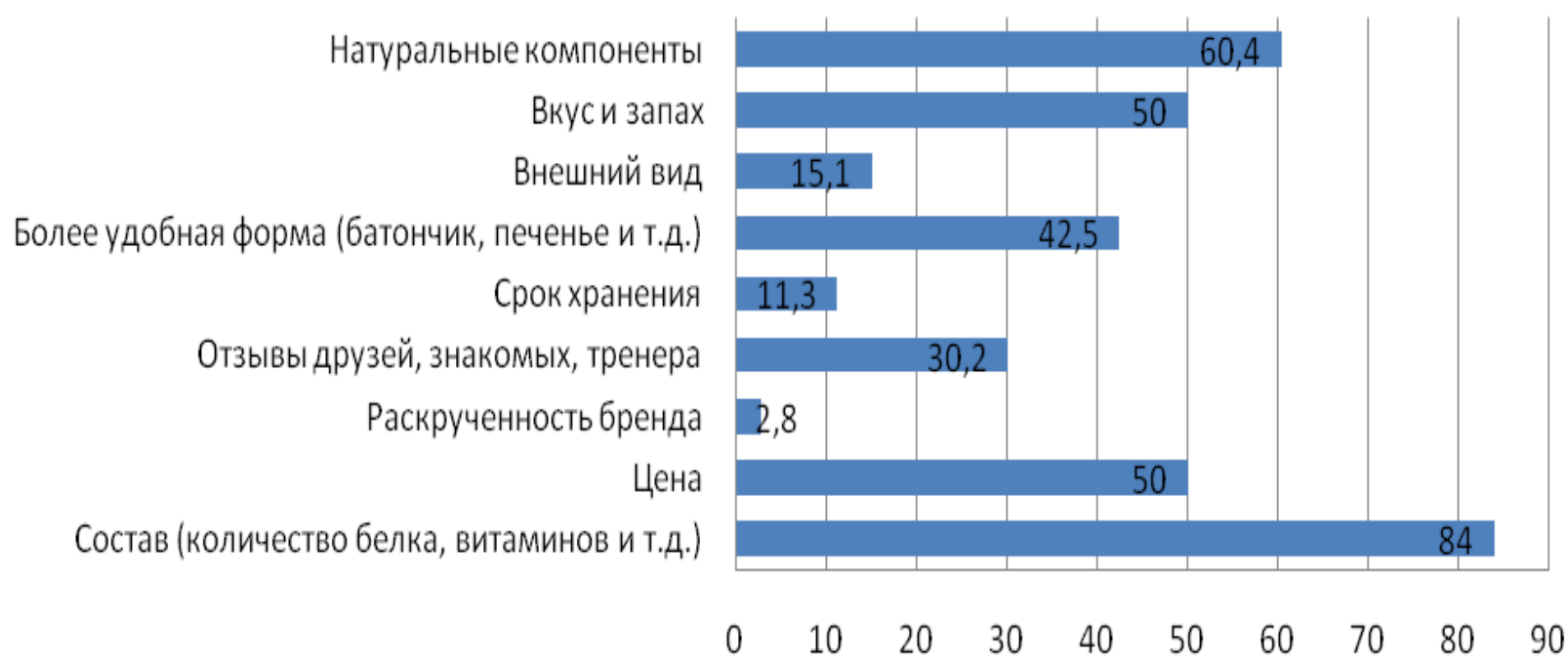

Рисунок 7 - Критерии выбора спортивного питания при покупке, \%

口а $\quad$ Вет $\quad$ Ватрудняюсь ответить

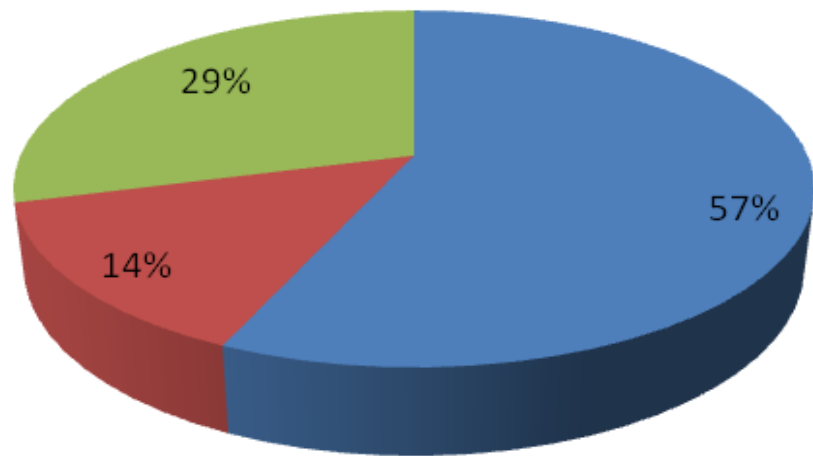

Рисунок 8 - Отношение респондентов к появлению нового батончика-снека на основе добавок из вторичного рыбного сырья и яблочного жмыха, \%

Таким образом, исходя из результатов социологического опроса, совершенствование рецептуры батончиков-снеков на основе протеинового гидролизата, полученного из голов копченой кильки, и вторичного яблочного сырья является актуальным и востребованным у основной массы потенциальных потребителей.

На основании полученных данных предложена технология изготовления протеинового батончика - снека (рис. 9). Основным моментом данной схемы является обработка вторичного яблочного сырья - яблочного жмыха. В результате его переработки образуется плодовая мякоть, которая далее используется как ингредиент в составе батончика-снека, и вытерки (косточки, плодоножки и т.д.), которые идут на дальнейшую переработку, например, кормовую добавку. Дальнейшие операции обеспечивают приобретение продуктом заданной формы в виде батончика-снека, а также сохранение всех компонентов их функциональных свойств.

В качестве дополнительных компонентов используются куриные яйца, предварительно измельченный кедровый орех, семена льна и пищевая соль. 


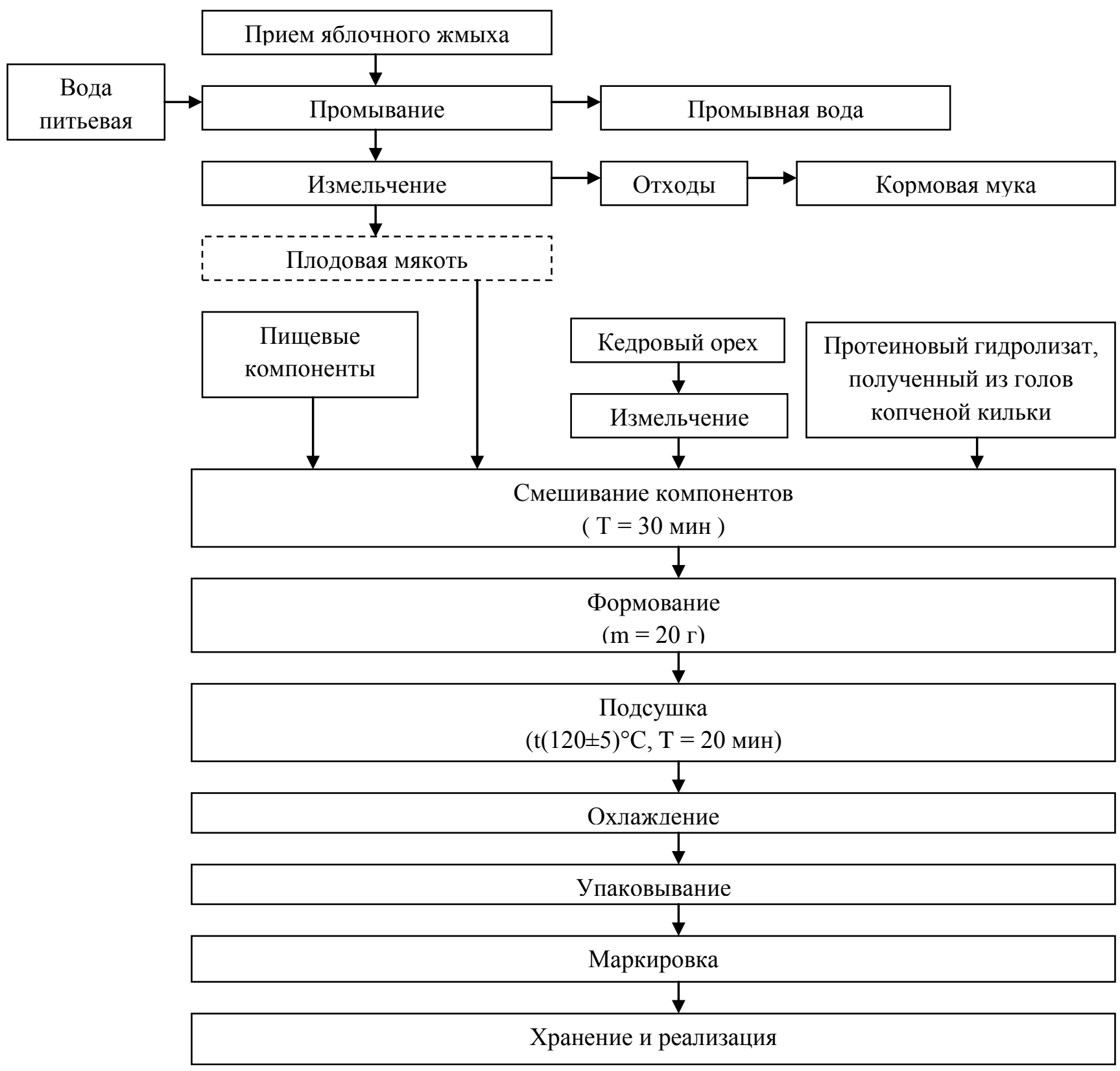

Рисунок 9 - Технологическая схема проектируемого протеинового батончика-снека, предназначенного для спортивного питания

\section{ЗАКЛЮЧЕНИЕ}

В результате проведенного маркетингового исследования в области спортивного питания выяснилось, что треть опрошенных считает, что спортивное питание необходимо употреблять всем, кто занимается спортом и ведет здоровый образ жизни. Часто покупаемая форма спортивных пищевых продуктов - это батончики $(55,7 \%)$ и коктейли $(22,3 \%)$. При этом большинство респондентов высказались положительно о новом протеиновом батончике-снеке $(57,0$ \%) на основе протеиновых гидролизатов, полученных из вторичного сырья - голов копченой кильки, и вторичного яблочного сырья.

Предложена технология изготовления и разработана технологическая схема получения протеинового батончика-снека, предназначенного для спортивного питания, главным моментом в которой является обработка вторичного яблочного сырья. 


\title{
СПИСОК ЛИТЕРАТУРЫ
}

1. Анализ современных тенденций в области производства продуктов питания для людей, ведущих активный образ жизни / Л. Г. Елисеева, Е. В. Крюкова, Л. В. Беркетова, Н. А. Грибова // Пищевая промышленность.-2017.-№1.- С. 16-19.

2. ГОСТ 34006 - 2016. Продукция пищевая специализированная. Продукция пищевая для питания спортсменов. Термины и определения. - Москва: Изд-во стандартов, 2017. - 11 с.

3. Clark A, Mach N. Exercise-induced stress behavior, gut-microbiota-brain axis and diet: a systematic review for athletes / A. Clark, N. Mach // Journal of the International Society of Sports Nutrition. - 2016;13:43. DOI: 10.1186/s12970-016-0155-6.

4. Manninen A. H. Protein hydrolysates in sports nutrition / A. H. Manninen // Nutrition and metabolism. - 2009;6:38. DOI: 10.1186/1743-7075-6-38

5. Назарова, М. В.Питание спортсменов / М. В. Назарова, Л. В. Бабенко // Вестник КНМУ. - 2012. - № 2. - C. 366-368.

6. Научно-методические подходы к развитию технологии белковых гидролизатов для специального питания. Часть 2. Функциональные свойства белковых гидролизатов, зависящие от специфичности протеолитических процессов / Ю. Я. Свириденко, Д. С. Мягконосов, Д. В. Абрамов, Е. Г. Овчинникова // Пищевая промышленность. - 2017. - № 6. - С. 50 - 53.

7. Обоснование рациональности параметром комплексной переработки вторичного сырья шпротных производств с применением метода высокотемпературного гидролиза / О. Я. Мезенова, Л. С. Байдалинова, Н. Ю. Мезенова [и др.] // Известия ТИНРО. - Т. 200. - 2020. № 1. - C. $210-220$.

8. Перфилова, О. В. Яблочные выжимки как источник биологически активных веществ в технологии продуктов питания / О. В. Перфилова // Промышленная биотехнология. - 2018. № 3. - С. 14-19.

9. Производство продуктов спортивного питания - одно из перспективных направлений в пищевой промышленности. Часть 1 / С. В. Штерман, М. Ю. Сидоренко, В. С. Штерман, Ю. И. Сидоренко // Пищевая промышленность. - 2017. - № 3. - С. 22 - 24.

\section{BARS - CNACK FOR SPORTS NUTRITION: MARKETING RESEARCH AND TECHNOLOGY}

Yu. O. Nekrasova, 4th year student, e-mail: yulya.nekrasova.1998@mail.ru

Kaliningrad State Technical University

\author{
O. Ya. Mezenova, Doctor of Technical Sciences, Professor, \\ e-mail: mezenova@klgtu.ru \\ Kaliningrad State Technical University
}

The analysis of the results of a marketing research of consumer preferences in the field of sports nutrition in Kaliningrad and the Kaliningrad region is presented. There have been studies of consumer preferences when choosing sports foods. A frequently bought form of sports nutrition is a bar, which corresponds to the shape of the product being designed - a protein bar - snack. The relevance of using protein hydrolysates obtained from smoked sprat heads and secondary apple raw materials as part of a protein product is substantiated. A technology and process flow chart for the production of a snack bar for sports nutrition has been developed.

Key words: marketing research, sport nutrition, bar-snack, protein hydrolysates, apple pomace 